PIOTR SZALSZA

WIEDEŃ

\title{
NIEZNANE FAKTY Z ŻYCIA ZOFII LISSY I JEJ NAJBLIŻSZEJ RODZINY
}

$W_{\mathrm{w}}$ marcu 2020 r. zakończyłem realizację filmu dokumentalnego poświęconego wybitnym Galicjankom, których życie lub działalność zawodowa związane

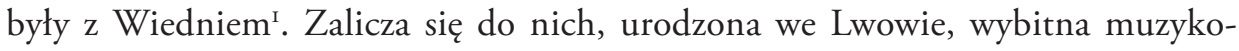
lożka Zofia Lissa. Możliwość przeprowadzenia przy tej okazji licznych kwerend w archiwach polskich, austriackich oraz ukraińskich pozwoliła zgromadzić wiele dokumentów, które w filmie wykorzystać zdołałem tylko w niewielkim zakresie. Niniejsza praca daje więc możliwość pełnego przedstawienia informacji i dokumentów, które podczas przygotowań do realizacji filmu na temat Zofii Lissy udało się zebrać.

Publikowane dotychczas biogramy Zofii Lissy podają, że urodziła się ona dnia I9 X 1908 r. we Lwowie. Tymczasem w zbiorach Archiwum Państwowym Akt Dawnych w Warszawie (dalej cyt. AGAD) znajduje się akt jej urodzenia, który poniżej przytaczam w całości:

L.P. I319.

Urodzenie - I9 paźdz[iernika] 1905 Lwów. Ul. Koralnicka² 6.

Dzień nadania imienia - 2I paźdz[iernika] I90s Lwów. Ul. Koralnicka 6.

Imię dziecięcia: Zosia [sic!]. Płeć - żeńska. Urodzenie: ślubne.

Imię i nazwisko ojca, jako też jego stan, zatrudnienie i miejsce zamieszkania - Noa vel Noach Lissa - c. i k. fotograf nadworny we Lwowie, żonaty.

Imię i nazwisko matki, jej stan i zmieszkanie, jako też jej nazwisko, zatrudnienie i miejsce zamieszkania jej rodziców - Chana ur. Buch zamieszkała we Lwowie, córka małżonków zmarłego lekarza Salomona Bucha i Giteli we Lwowie.

I Wielkie Galicjanki, czyli ze Lwowa do Wiednia / Grosse Galizierinnen oder-von Lemberg nach Wien, film dokumentalny, I25 min. Producent TAKT Polsko-Austriackie Stowarzyszenie Kultury, Wiedeń 2020. Film realizowany w ramach Roku Kulturalnego „Austria-Ukraina”.

2 Ulica Koralnicka we Lwowie, obecnie ul. Wołoszyna. 
Własnoręczny podpis z wymienieniem zatrudnienia i miejsca zamieszkania kumów lub świadków, sandeka lub szamesa Izydor Buch rewident c.k. kolei państw. we Lwowie. Filip Buch agent kolei w Wiener Neustadt ${ }^{3}$. Akuszerka - L. Bum. We Lwowie.

Uwaga: Rodzice zaślubieni we Lwowie dn. I marca I898 - wedle ks[ięgi] zaślub[in] z r[oku] I898 str. 68 , poz. $68^{4}$.

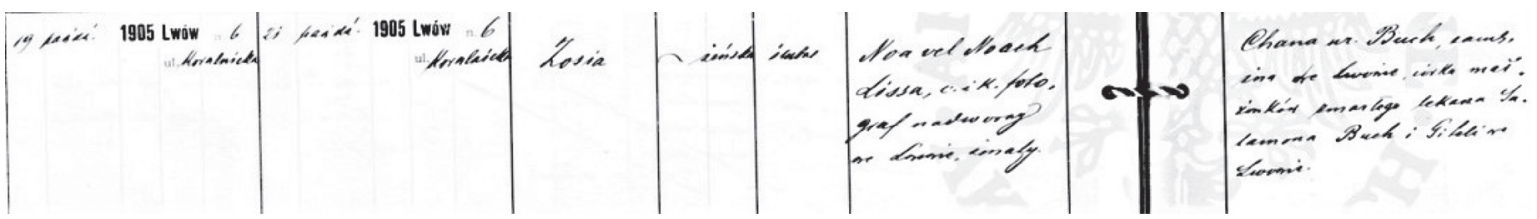

Il. I. Akt urodzenia Zofii Lissy

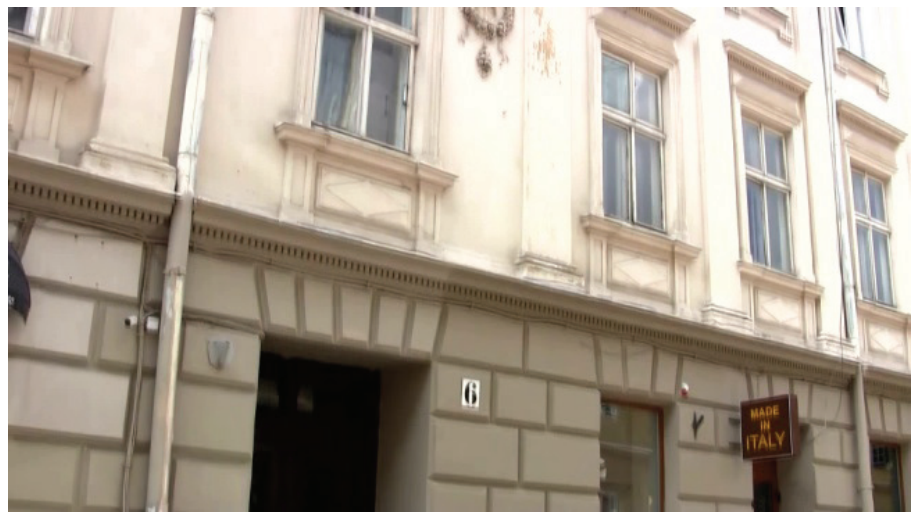

Il. 2. Dom urodzin Zofii Lissy przy ul. Koralnickiej 6 we Lwowie (fotografia współczesna autora)

Odszukany akt urodzenia Lissy uzupełnić możemy drugim nieznanym wcześniej dokumentem notarialnym, czyli aktem ślubu rodziców:

L.P. 68.

Noa vel Nojach Lissa, rodem z Żytomierza, Wołyńskiej Guberni w Rosyi, fotograf, zamieszkały we Lwowie przy ul. Karola Ludwika n[r] 3., syn Szajego Lissa, kupca i rzekomo tegoż ślubnej małżonki Rebeki Lissa, ur. w Uładowce w Rosyi wspólnie zamieszkałych. Wiek: 27 lat i 8 i I/2 miesięcy. Stan wolny.

3 Izydor i Filip Buch to krewni Chany Buch, niewykluczone, że jej bracia. O Izydorze wiadomo, że mieszkał we Lwowie przy ulicy Jachowicza I6 (obecnie Akademika Romana Kuczery), zob.: Księga Adresowa Król. Stot. Miasta Lwowa, opr. i wyd. Franciszek Reichman, t. 17, Lwów 1913, s. 52. Izydor Buch był wieloletnim, szanowanym i odznaczanym urzędnikiem kolei cesarskich, o czym informuje gazeta Reichspost 24 (I9I7) nr 408 z I7 IX, s. 4. Jego nazwisko widnieje też na listach osób, które w roku I9I4 uciekały przed wojskami rosyjskimi ze Lwowa do Brna, por.: Księga pamiątkowa i adresowa wygnańców wojennych z Galicji i Bukowiny I9I4-I9IS oraz Album pamiątkowe, cz. 3, Prowincja i Bukowina, opr. „według planu” Antoniego Chmurskiego, Wiedeń I9I5.

4 AGAD, Księgi metrykalne gmin wyznania mojżeszowego z terenów tzw. zabużańskich, I789-1943, Księga urodzin izraelickiego okręgu metrykalnego miasta Lwów na rok 1905, sygn. 2002, s. 68. 
Anna recte Chana Buch, rodem ze Stryja, córka małżonków b.p. lekarza w Stryju Salomona Buch i Giteli Buch, prywatki [?], we Lwowie przy ul. Krasickich 15. zamieszkałej. Lat 30 i I/2 miesięcy. Stan / wolna. I/:pierwszy:/marzec I898 roku.

Funkcjonujący przy zaślubinach rabin (szkolnik): Rabin dr J. Caros, szkolnik i kaznodzieja. Świadkowie i ich zatrudnienie: Eliasz Körner, kantor. Wolf Rein, sługa - obaj we Lwowie $^{6}$.

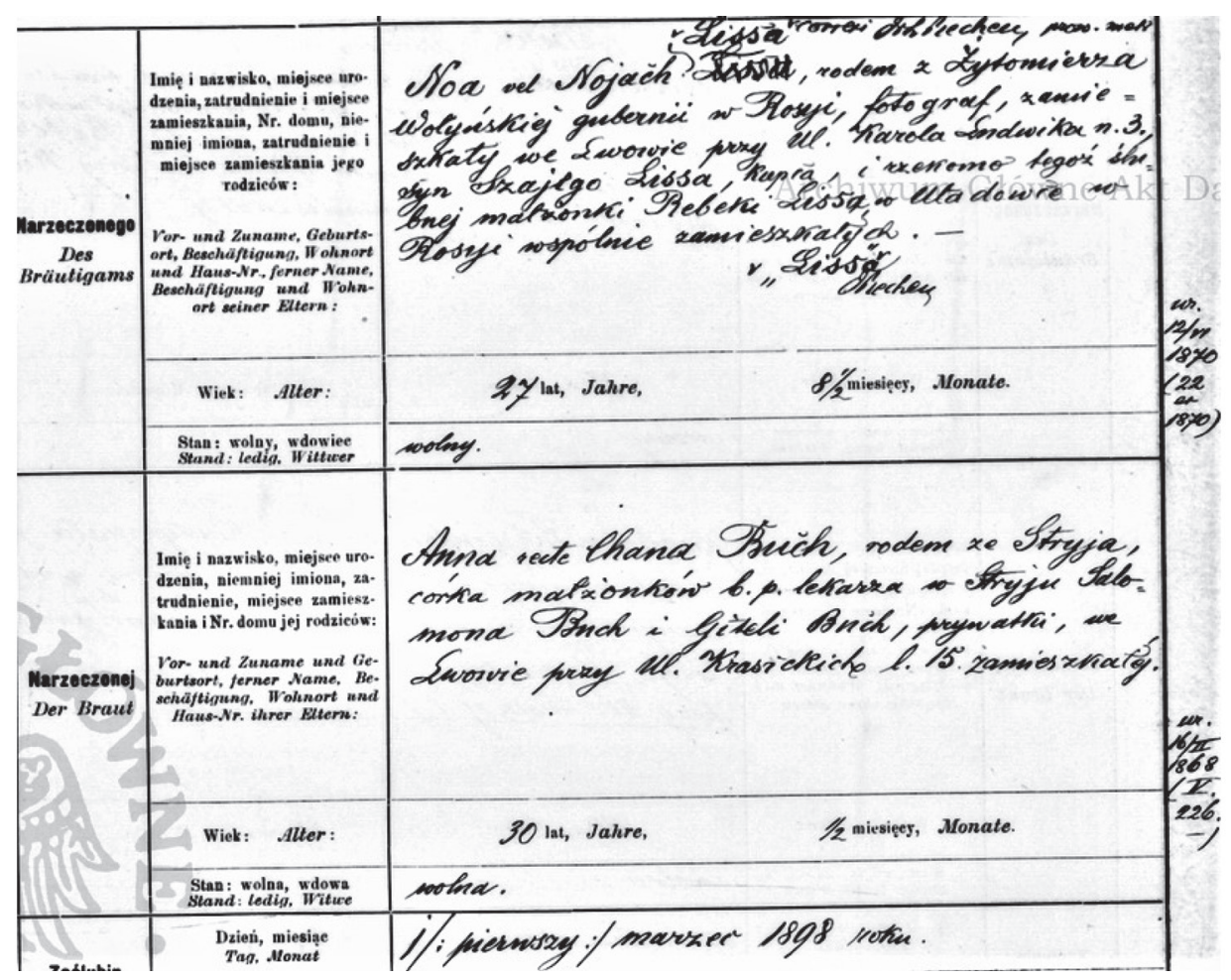

Il. 3. Akt zaślubin rodziców Zofii Lissy

Przywołany wyżej zapisy nie tylko korygują m.in. panujące przez lata przekonanie, że Zofia ukończyła naukę w Konserwatorium jako piętnastolatka (w roku I924), lecz także pozwalają na poznanie szczegółów dotyczących jej antenatów. Na ten wsparty źródłami obraz nakładają się czasem różne w szczegółach informacje z dokumentów (ankiet, życiorysów) spisanych przez badaczkę w dorosłym życiu, w trakcie biegu jej kariery naukowej na Uniwersytecie Warszawskim.

5 Dr Jecheskel Caro mieszkał we Lwowie przy ul. Kościuszki 3, zob.: Księga Adresowa Król. Stot. Miasta Lwowa, s. 57. Pełnił funkcję naczelnego rabina. Przez wiele lat zasiadał w radzie miasta. Zmarł 24 XII I9I5 r. w Wiedniu, gdzie znalazł się w roku I9I4, w następstwie ucieczki ze Lwowa przed nadciągającymi wojskami rosyjskimi, zob.: Jüdische Korrespondenz I (I9I5) nr 20 z 30 XII, s. 4.

6 AGAD, Księgi metrykalne, 1789-1943, Księga zaślubin izraelickiego okręgu metrykalnego miasta Lwów na rok 1898, sygn. 2429 , s. 210. 
W zbiorach Archiwum uczelni znajduje się m.in. kilka, wypełnionych przez Lissę w 1. I950-72, kwestionariuszy osobowych7 ${ }^{7}$. Ich lektura ujawnia nieścisłości co do danych związanych zarówno z jej życiem, jak i karierą zawodową. W stosunku do informacji zawartych w akcie urodzenia, w kwestionariuszach tych jedna informacja nie ulega nigdy zmianie - jest nią niezgodna z prawdą data roku urodzenia: 1908.

I tak np. w kwestionariuszu z roku 1962 znajduje się zapis o polskiej narodowości ojca i spolszczona wersja imienia, które pojawiło się w dokumentach austriackich Mikołaj. Pojawiają się też skąpe dane na temat losu rodziny w latach trwania I wojny światowej. W kwestionariuszu z roku I950 Lissa informuje mianowicie, że jej rodzina przebywała w Wiedniu od roku I9I4 do I919 ${ }^{8}$, zaś ojciec walczył w tym czasie w armii austriackiej na froncie włoskim. W naddunajskiej stolicy dziewczynka miała chodzić do szkoły powszechnej i ją ukończyć, a w roku I9I9, po powrocie wraz z rodzicami do Lwowa, rozpocząć miała naukę w Gimnazjum im. Królowej Jadwigi oraz w Konserwatorium Muzycznym (fortepian i organy) ${ }^{9}$. Okazuje się jednak, że np. w sprawozdaniu wspomnianego Gimnazjum z tego okresu nazwisko Zofii Lissy nie figuruje w spisach uczennic żadnej z klas ${ }^{\mathrm{IO}}$.

Z dostępnych dzisiaj zapisów archiwalnych, związanych z pobytem rodziny w Wiedniu w latach Wielkiej Wojny warto przytoczyć dane, które wynikają z dokumentu meldunkowego, a które mówią, że Nicolaus-Noa Lissa, ur. I2 VI I870 r. w Uładowce, przebywał wraz ze współzameldowaną małżonką Anną ur. II V I874 r. ${ }^{\text {II }}$ i współzameldowaną Sophią (dziecko) ur. I9 X i905 r. pod adresami meldunkowymi: Steinfeldergasse $28 \mathrm{w}$ podwiedeńskim Mödling i Glasergasse 5/28 w 9. Dzielnicy (6 X I9I4-7 V I9I5), oraz Speisingergasse 30/2 w I3. Dzielnicy (7 V I9I5-28 XII I9I5), po czym nastąpiło wymeldowanie do Lwowa ${ }^{\mathrm{I} 2}$. Warto zwrócić uwagę, że pod adresem w Mödling mieścił się sierociniec, w którym umieszczano także m.in. rodziny uciekinierów z Galicji13.

Fakt powrotu Noa Lissy do Lwowa na przełomie roku I9I5 i I9I6 potwierdza informacja, którą przeczytać można w Kurierze Lwowskim ze stycznia I9I6 r.:

7 Archiwum Uniwersytetu Warszawskiego, teczka sygn. WG-prof. i iI5. Za pomoc w uzyskaniu tych danych autor niniejszej pracy dziękuję bardzo Pani Monice Pal.

8 Rodzina Lissów wyjechała do Wiednia z podobnych powodów, z jakich znalazł się tam, wspomniany w przyp. 5 , rabin Caro.

9 Inaczej niż np. w haśle osobowym Zofii Lissy, gdzie mowa jest o fortepianie i teorii muzyki, zob.: Elżbieta Dziębowska, „Lissa, Zofia”, w: Encyklopedia Muzyczna PWM, red. Elżbieta Dziębowska, t. 5, Kraków 1997, s. 368-370 (zob. s. 368).

Io Zob.: Gimnazjum im. Królowej Jadwigi: Sprawozdanie za rok szkolny 1920-2I, t. 8, Lwów 192I, zob. s. II-I6: „Wykaz uczennic w roku sprawozdawczym”.

II Podczas gdy z cytowanego aktu zaślubin wynika, że Anna (Chana) Buch urodziła się w I868 roku.

I2 W oryginale - „Abgemeldet: Lemberg” (wymeldowanie: Lwów), zob.: Wiener Stadt- und Landesarchiv Wypis z formularzy meldunkowych, sygn. MA 8-B-MEW-4504.

I3 W omawianym okresie do stolicy Austrii przybyło ze Wschodu kilkaset tysięcy uciekinierów, głównie narodowości polskiej i żydowskiej. Z braku miejsc w samym Wiedniu umieszczano wiele rodzin w okolicznych miasteczkach, także w Mödlingu. 
Fotograf Lissa, właściciel zakładu przy ul. Akademickiej stwierdził w swojem mieszkaniu po powrocie [podkreśl. P.S.] brak srebra stołowego, futer itp. Szkodę oblicza na około 4.000 koron $^{14}$.

Lwowski świat przestępczy nie oszczędził rodziny Lissa także późną jesienią następnego, I9I7 r.:

Złodzieje grasują. P. Anna Lissa doniosła policji, że wczoraj jakiś nieznany sprawca dostawszy się przez okno do zakładu fotograficznego przy ul. Akademickiej I8, skradł aparat fotograficzny z przyrządem grającym wartości 400 kor., oraz dwa kawałki sukna wartości 50 kor. ${ }^{15}$

Biorąc pod uwagę informacje podane przez Zofię Lissę w cytowanych już kwestionariuszach na temat stałego pobytu rodziny w Wiedniu w l. 1914-19, można zauważyć, że w przypadku rodziców na pewno nie był to pobyt stały, bowiem w 1. I9I6 i I9I7 co najmniej bywali oni we Lwowie, a może nawet ponownie w mieście mieszkali na stałe. Wszak w Wiedniu nie byli już zameldowani. Co w tym okresie dokładnie działo się z dziesięcioletnią Zofią, do której szkoły w Wiedniu uczęszczała, gdzie mieszkała - nie wiadomo.

Warto jeszcze zwócić uwagę na wymienianą w Kurierze Lwowskim ulicę Akademicką I8. Tam właśnie znajdował się, niezwykle popularny we Lwowie, zakład fotograficzny Jakuba Hennera, którego właścicielem od początku stulecia był Noa Lissa - postać w mieście rzeczywiście znana i szanowana ${ }^{16}$.

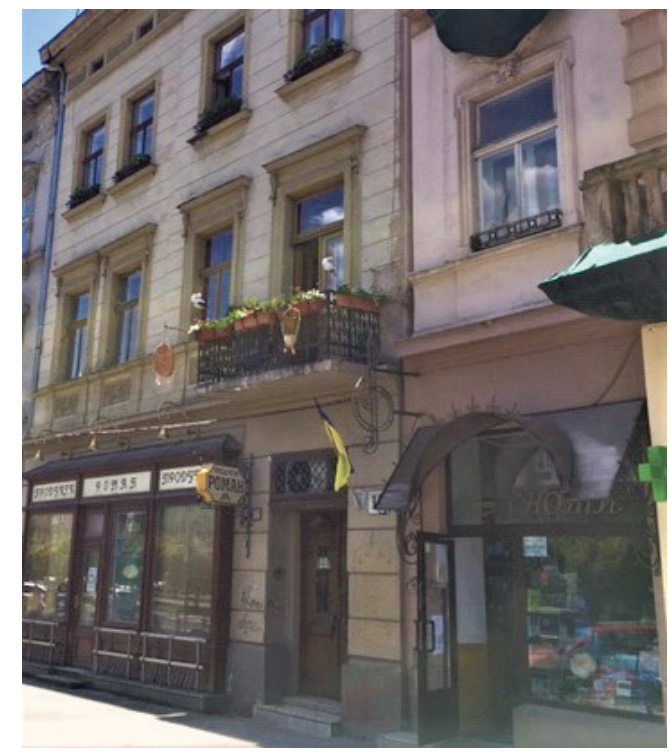

Il. 4. Dom przy ul. Akademickiej I8

I4 Kurier Lwowski 34 (I9I6) nr I2 z 8 I, s. 3.

I5 Kurier Lwowski 35 (I9I7) nr 55I z 24 XI, s. 5.

I6 Ówczesna ulica Akademicka we Lwowie to obecnie Prospekt Szewczenki. 
Lissa prowadził działalność dwutorowo. Z jednej strony świadczył on usługi fotograficzne na rzecz mieszkańców Lwowa, także w filii zakładu, znajdującej się w Stryju, skąd pochodziła Chana Buch i jej rodzina. Z drugiej strony - Noa Lissa rozwijał swoje umiejętności w dziedzinie fotografii artystycznej, odnosząc na tym polu sukcesy. Pierwszą, ważną informację, na temat drogi zawodowej Noa Lissy, opublikował Kurier Lwowski z roku I9oo:

Śmiem uświadomić Szanowną P.T. Publiczność, że nabyłem na własność, od wielu lat istniejący, pierwszorzędny Zakład fotograficzny, po c.k. fotografie nadwornym - panu J. Hennerze ${ }^{\mathrm{I} 7}$. Obecnie pozyskałem dla tego Zakładu pierwszorzędną siłę z Monachium i uzupełniłem atelier najnowszemi aparatami, tak że pod względem techniki fotograficznej postawiłem obecnie mój zakład na wysokości pierwszorzędnych zakładów europejskich i tuszę sobie, że artystycznym wykonaniem wszelkich zamówień i możliwie przystępnymi cenami potrafię zadowolić nadal dotychczasowych P.T. Klientów zakładu i zjednać sobie dalszą Klientelę tak w stolicy samej, jak i w całym kraju. W tem przekonaniu poleca swój zakład wielce Szanownej P.T. Publiczności N. LISSA właściciel zakładu artystyczno-fotograficznego, dawniej J. Hennera, ul. Akademicka $18^{18}$.

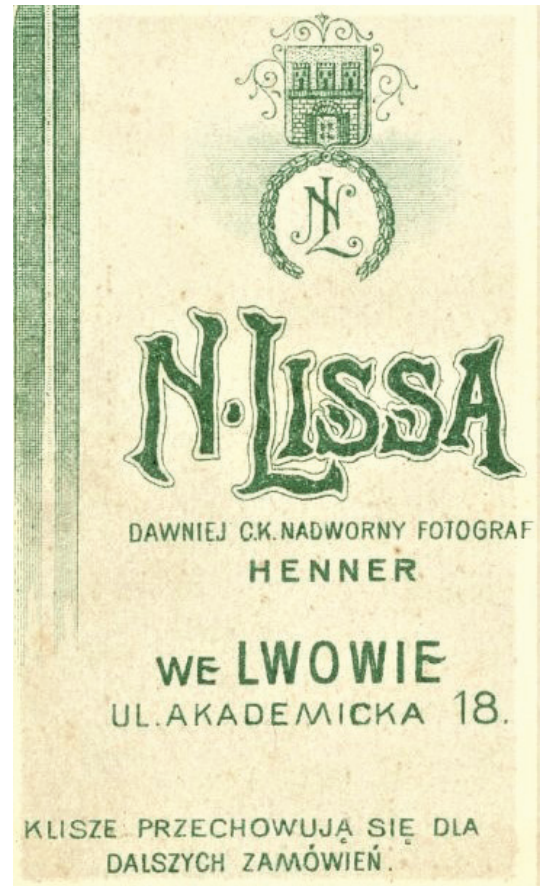

Il. 5. Rewers jednej z fotografii pochodzącej z zakładu Noa Lissy

I7 W rzeczywistości Noa Lissa nie kupił „Zakładu Hennera” od tegoż osobiście, tylko od niejakiego Józefa Popiela (w roku I899), który nabył firmę od pierwszego właściciela rok wcześniej, pozostawiając jednak nazwę „Zakład fotograficzny J. Hennera”, por. reklamę zamieszczoną przez Popiela w Kurierze Lwowskim I6 (I898) nr $230 \mathrm{z}$ I8 VIII, s. IO.

I8 Kurier Lwowski I8 (I900) nr 250 z 9 IX, s. 5. 
Można śmiało stwierdzić, że niecałe dwa lata po ślubie pozycja zawodowa Noa Lissy była ugruntowana. Z usług jego zakładu chętnie korzystali znaczący obywatele miasta, jak na przykład prof. Ołeksandr Kołessa ${ }^{\text {I9 }}$ : zachowała się fotografia z roku 1903, na której widnieje on wraz z małżonką oraz jednoroczną córeczką Lubką, później wybitną pianistką ukraińską (zob. il. 6).

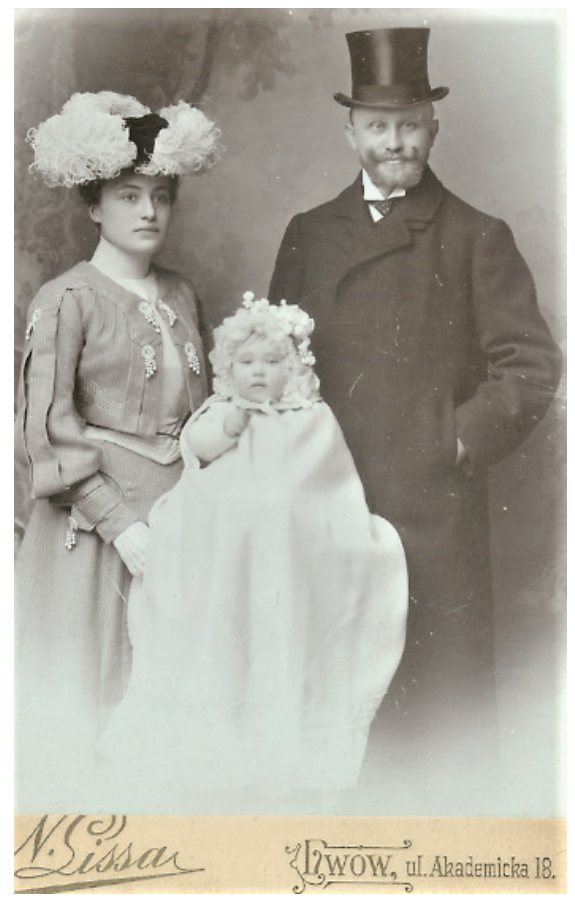

Il. 6. Rodzina Ołeksandra Kołessy na fotografii wykonanej w studio fotograficznym Noa Lissy ${ }^{20}$

Lissa dbał także o reklamę poza Lwowem. Jeszcze w tym samym roku, w wychodzącym w Wiedniu i w Lipsku poczytnym fachowym periodyku zajmujacym się sprawami fotografiki - Photographische Korrespondenz - w majowym wydaniu znaleźć można ogłoszenie: „Atelier N. Lissy - cesarsko-królewskiego fotografa dworskiego” ${ }^{21}$.

Noa Lissa chętnie realizował się w dziedzinie fotografii artystycznej. W roku 1907 Kurier Lwowski2 ${ }^{22}$ wymienia go w grupie zdobywców Złotego Medalu w ramach Wystawy Przyrodniczo-Lekarskiej we Lwowie (zob. il. 7$)^{23}$.

I9 Ołeksandr Kołessa (I867-1945), wybitny ukraiński literaturoznawca, etnograf, lingwista i polityk. Brat etnomuzykologa Fiłareta, ojciec pianistki Lubki i kompozytora Mykoły Kołessów.

20 Kopia fotografii ze zbiorów prywatnych autora.

2I Photographische Correspondenz 40 (1903) nr 5, s. IIO.

22 Kurier Lwowski 25 (1907) nr 342 z 25 VII, s. 2.

23 Nagrodzona fotografia zachowała się w zbiorach pani Danuty Thiel-Melerskiej (sygn. I404). Za zgodę na publikację fotografii autor niniejszej pracy składa serdeczne podziękowanie. 

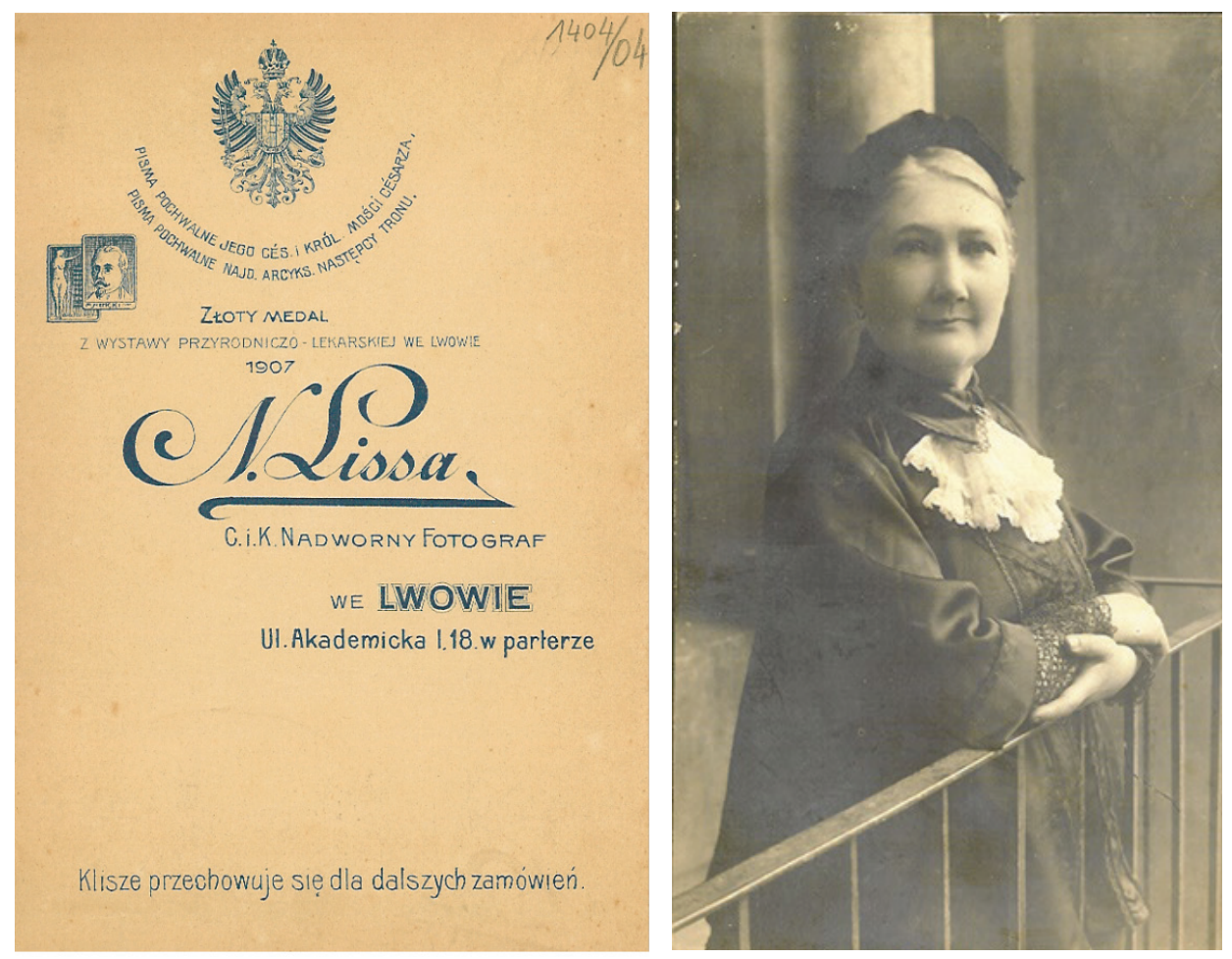

Il. 7-8. Wyróżnienia Noa Lissy, m.in. zdobywcy Złotego Medalu Wystawy Przyrodniczo-Lekarskiej we Lwowie i nagrodzona fotografia, portret nieznanej starszej kobiety

Analiza niektórych lwowskich ksiąg adresowych ${ }^{24} \mathrm{z}$ omawianych lat pozwala odnotować kilka domicylów związanych z rodziną Lissów. Była już mowa o ulicy Akademickiej, a także Koralnickiej, gdzie na świat przyszła Zofia. Pojawia się jeszcze adres przy ulicy Małeckiego nr 625, z Noa Lissą jako właścicielem mieszkania, gdzie zameldowana była babcia Zofii Lissy - Gizela (Gitela) Buch, czyli matka Anny (Chany). Rzut oka na plan miasta Lwowa pozwala skonstatować, że trzy domicyle Lissów (Akademicka, Koralnicka, Małeckiego) znajdują się bardzo blisko siebie. Do tego dochodzi jeszcze adres przy ul. Akademickiej 8, gdzie w roku 1916 mieszkała taż sama babcia Gizela, „wdowa po lekarzu”, czyli Salomonie Buchu ze Stryja. Na marginesie można tu dodać, że chirurg Salomon Buch od roku I87I służył, w stopniu podporucznika, jako lekarz asystent $\mathrm{w}$ stacjonującym w mieście 65. batalionie piechoty. Po kilku latach, w roku I879, z powodu inwalidztwa zwolniony został ze służby wojskowej. Zmarł w Stryju w I88I r. ${ }^{26}$.

26 Wiener Zeitung I69 (I87I) nr I58 z 25 VI, s. 6.; Militär Zeitung 20 (I879) nr 75 z I7 IX, s. 596. 
Aby zamknąć temat matki, Anny (Chany), należy powrócić do wspomnianych już kilkakrotnie kwestionariuszy, które Zofia wypełniała już po II wojnie światowej, w Warszawie. Mianowicie na postawione w kwestionariuszu z I950 r. jedno z pytań - „czy ktoś z członków rodziny był prześladowany przez okupanta i za co? W jakiej formie?” - odpowiedziała: „matka zabita”. Tymczasem z zachowanego w AGAD aktu zgonu matki wynika, że niejaki dr Kielanowski I8 IV I9I9 r. poświadczył zgon Anny Lissy, żony fotografa, zamieszkałej we Lwowie, przy ul. Akademickiej 8. W rubryce dotyczącej choroby i rodzaju śmierci wpisał: gruźlica płuc ${ }^{27}$. W cytowanym kwestionariuszu badaczka podaje także rok, w którym zmarł jej ojciec: 1935, co faktycznie zgodne jest z także zachowanym w AGAD aktem zgonu Noa (tu jako Noe) Lissy. Z wpisu dowiadujemy się ponadto, że zmarły w wieku 65 lat był żonaty, a przyczyną śmierci było otrucie ${ }^{28}$.

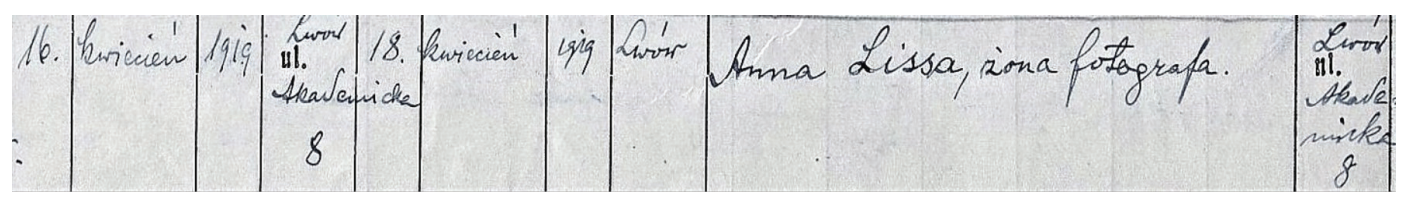

Il. 9. Akt zgonu Anny (Chany) Lissa

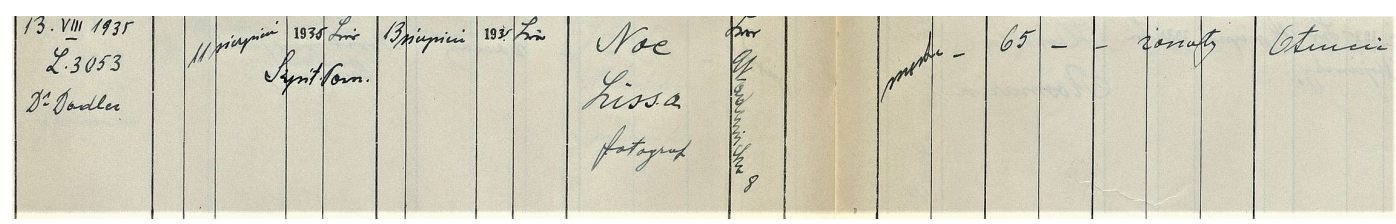

Il. Io. Akt zgonu Noa Lissa

Na zakończenie pozostaje przedstawienie jeszcze jednej nieznanej informacji, tym razem dotyczącej rodzeństwa Zofii. Znów rezultat dały poszukiwania w Księgach Izraelickich w AGAD, w których zachował się wpis o urodzinach I6 I i nadaniu 20 I I900 r. imion Julia Karolina dziecku płci żeńskiej, z rodziców Noa i Chany Lissa ${ }^{29}$.
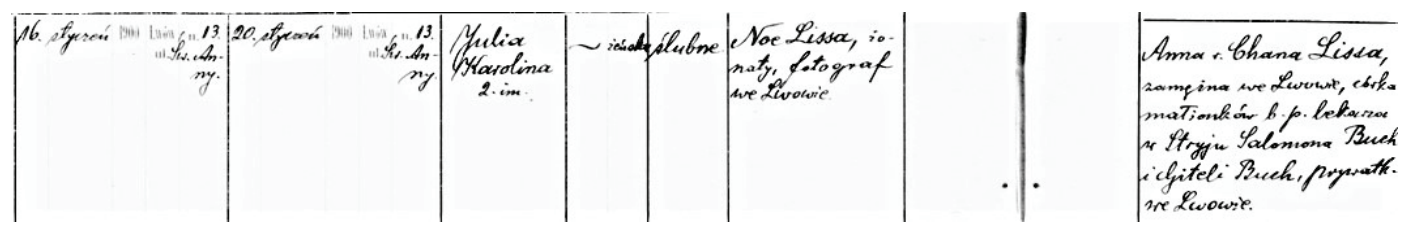

Il. II. Akt urodzenia Julii Karoliny, siostry Zofii Lissy

27 AGAD, Księgi metrykalne, I789-1943, Księga zmarłych izraelickiego okręgu metrykalnego Lwów na rok I9I5-I919, sygn. 3516, s. I48.

28 AGAD, Księgi metrykalne, I789-1943, Księga zmarłych izraelickiego okręgu metrykalnego Lwów na rok I9I5-I9I9, sygn. 3549, s. I50.

29 AGAD, Księgi metrykalne, I789-I943, Księga urodzin izraelickiego okręgu metrykalnego miasta Lwów na rok 1900, sygn. 2I3I, s. 24 . 
Julia Karolina, starsza siostra, urodziła się więc pięć lat przed przyjściem na świat Zofii. Według zachowanego aktu zgonu dziewczynka zmarła w wyniku gruźliczego zapalenia opon mózgowych, w drugim roku życia, $22 \mathrm{X} 1902 \mathrm{r}^{30}$.
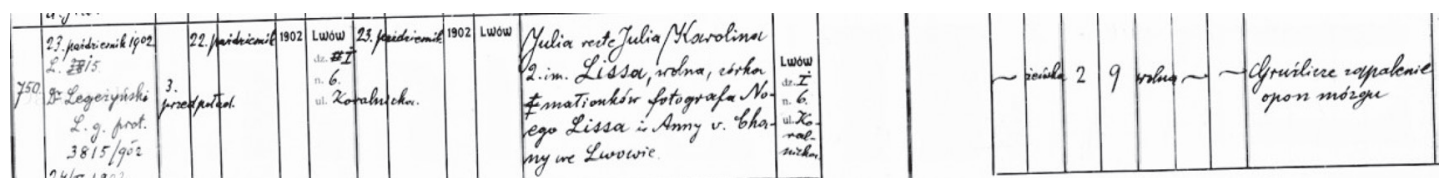

Il. I2. Akt zgonu Julii Karoliny

Przedstawione powyżej nieznane fakty związane przede wszystkim z pierwszym okresem życia Zofii Lissy skłaniają do przedstawienia wniosków natury ogólnej. Otóż możliwość opisywania życia, twórczości i działalności wybitnych postaci to zjawisko istotne dla badaczy w każdej epoce. Bywa, że z przyczyn obiektywnych docieranie do faktów jest zadaniem trudnym, czasem wręcz niemożliwym. Jest więc obowiązkiem kolejnych pokoleń uzupełnianie, weryfikowanie, a przez to i wzbogacanie wiedzy, jaką dotąd dysponowano. Tym razem odszukane źródła pomogły w skorygowaniu danych na temat życia jednej z ikon polskiej muzykologii.

\section{BIBLIOGRAFIA}

Dziębowska, Elżbieta. „Lissa, Zofia”. W: Encyklopedia Muzyczyna PWM. Częś́ biograficzna, red. Elżbieta Dziębowska. T. 5, 368-370. Kraków: PWM, 1997.

Reichman, Franciszek, opr. i wyd. Księga Adresowa Król. Stot. Miasta Lwowa. T. 17. Lwów: Wydawca Franciszek Reichman, 1913.

Sprawozdanie Dyrekcji państwowego Gimnazjum realnego żeńskiego im. Królowej Jadwigi we

Lwowie za rok szkolny 1920-2I. T. 8. Lwów: Nakładem Funduszu Naukowego, I92I.

UNKNOWN FACTS FROM THE LIFE OF ZOFIA LISSA AND HER CLOSEST FAMILY

During my work on the film Wielkie Galicjanki [Great Galician women], devoted to women born in the historical territory of Galicia (Halychyna) at the turn of the twentieth century and associated with the city of Vienna, I came across documents and information concerning the life of the eminent Lviv-born Polish musicologist Zofia Lissa, held in Austrian, Ukrainian and Polish archives.

30 AGAD, Księgi metrykalne, 1789-1943, Księga zmarłych izraelickiego okręgu metrykalnego Lwów na rok 1902, sygn. 2286, s. I25. 
These sources mostly concern her childhood and youth. The numerous previously unknown or unpublished documents described in this article have made it possible to reveal or revise information relating to Zofia, as well as her parents, sister, grandparents and relatives on her mother's side, and also to the period preceding her birth. Most importantly, my archive research has made it possible to correct the hitherto inaccurately given date of Zofia Lissa's birth.

Translated by Tomasz Zymer

Słowa kluczowe / keywords: Zofia Lissa, Noa Lissa, Chana Buch-Lissa, Julia Karolina Lissa, Salomon Buch, Izydor Buch, Jecheskel Caro, ul. Akademicka (Lwów) / Akademicka Street (Lvov, Lviv), Wiedeń / Vienna, Archiwum Główne Akt Dawnych w Warszawie / Central Archives of Historical Records in Warsaw

Piotr Szalsza, absolwent Akademii Muzycznej w Katowicach. Pracował w redakcjach muzycznych Telewizji Polskiej jako autor, reżyser i redaktor (1967-8I). Od I983 r. działa jako scenarzysta, reżyser i tłumacz w Wiedniu. Jest twórcą licznych muzycznych portretów filmowych, m.in. Fryderyka Chopina, Wojciecha Kilara, Witolda Lutosławskiego, Krzysztofa Pendereckiego, Witolda Szalonka, Karola Szymanowskiego. Autor kilkudziesięciu haseł w Österreichisches Musiklexikon oraz książek o Karolu Szymanowskim (1985) i Bronisławie Hubermanie (200I). Był ponadto organizatorem sympozjów, konferencji naukowych i wystaw tematycznych poświęconych m.in. Chopinowi, Szymanowskiemu, Maksowi Kalbeckowi i Teodorowi Leszetyckiemu. piotr.szalsza@ai.net

\section{Film o kwartalniku MUZYKA}

